\title{
Gendered Devitalisations: A Double Reading of the "Vagina Dentata" Motif in India
}

\author{
Romina Rossi \\ Civiltà dell'Asia e dell'Africa - Subcontinente Indiano \\ Università degli studi di Roma "La Sapienza" \\ romina.rossi86@gmail.com
}

\begin{abstract}
The motif of the "Vagina Dentata" appears in various Hindu myths and tales belonging to Indic folklore, yet its iconic relevance extends beyond symbolic and religious fields and overlaps with the wider sphere of the discourses on gender and sexuality. Based upon this premise, the paper aims to illustrate the motif of the "toothed vagina" on two interconnected levels: on the first one, it offers a psychoanalytical codification of the symbol and of the violence connected with the removal of the "teeth," while on the second it scrutinises the "extirpation" in the light of the patriarchal endeavour to subjugate women through abuse and debasement. The concluding part of the paper advances a metaphorical suggestion around the "vagina dentata" symbol, pointing to the resources implied in the affirmation of women's voices in the public domain.
\end{abstract}

Keywords: gender, sexuality, religion, vagina dentata, psychoanalysis, symbol, myth, folklore, metaphor

Słowa kluczowe: płeć, seksualność, religia, vagina dentata, psychoanaliza, symbol, mit, folklor, metafora

\section{Introduction: the life of symbols}

The concept of "symbols" occupies a central role in the psychoanalytical discourse, but the task of univocally defining this concept is problematic. A generic definition does not prove adequate to explain the psychoanalytical symbol, whose peculiarity has been discussed, among others, by Ernest Jones in his essay on the theory of symbolism. ${ }^{1}$ For the sake of brevity, I will say that the prominent feature that distinguishes

\footnotetext{
1 E. Jones, Papers on Psycho-analysis, $5^{\text {th }}$ editon, London 1977.
} 
the psychoanalytical concept of the "symbol" is its property of concealing a secondary, latent meaning, behind the surface of a manifest one. ${ }^{2}$ As Jones noted, "Only what is repressed is symbolised; only what is repressed needs to be symbolised." 3 The latent meaning of the symbol is unconscious, therefore it needs to be interpreted. ${ }^{4}$ In his tenth introductory lesson on psychoanalysis, Freud pointed out that, despite the remarkable availability of figurative representations that emerge in dreams, myths, tales, folkloric narrations, jokes and so on, the number of themes symbolised is rather limited: namely, as well as sexuality, the "human body as a whole, parents, children, brothers and sisters, birth, death, nakedness and a few others." ${ }^{5}$ The reason for this may possibly be that psychoanalytic symbols originate in the first stages of childhood, in connection with bodily perceptions and the development of the first object-relations, through the interaction of instincts, drives, defences and perceptual impressions. ${ }^{6}$

In this paper, the motif of the "vagina dentata" will be treated in a twofold way, mirroring the presented readings. Following the theorisation advanced by Henrik Enckell, ${ }^{7}$ I consider it as a symbol in the first part, and as a potential metaphor in the second. Enckell distinguishes between two representational structures that accommodate the process of symbolisation ${ }^{8}$ : the symbol, as an instrument belonging to "archaeology," and the metaphor as specific for "teleology." Drawing from Ricoeur," Enckell states that psychoanalysis makes use of both the "archaeological" and the "teleological" models of reflection. The former considers symbols as representations with structured double meanings requiring interpretation as a process through which individuals look back at their temporal past in search of the truth behind the manifest meaning. The proper locus of reflection therefore lies in childhood: when interpreting symbols, we are looking for sediments of the Self; we are in search of memories. However, according to the "teleological" model, the meaning of the Self is not in the past, nor in the present: it is yet to come, and it will happen through a reflective procedure capable of generating new meanings and new "worlds of possibilities." Through the subversion of the ordinary logic, metaphor urges the speaker towards the creation of new connections, of new semantic and referential possibilities: by reading metaphors, we move towards the future and its potentialities. ${ }^{10}$

${ }^{2}$ H. Enckell, Reflection in Psychoanalysis: On Symbols and Metaphors, "International Journal of Psychoanalysis" 2010, vol. 91, pp. 1093-1114, p. 1096.

${ }^{3}$ E. Jones, op. cit., p. 116.

${ }^{4}$ S. Freud, A General Introduction to Psychoanalysis, New York 1920, lesson XI, p. 141.

${ }^{5}$ Ibidem, lesson X, pp. 125-130; cf. J. Laplanche, J.B. Pontalis, Enciclopedia della Psicoanalisi. Tomo Secondo, Bari 2010, pp. 590-595.

${ }^{6}$ S. Freud, A General Introduction to Psychoanalysis, op. cit., lesson XIII, pp. 167-179; H.P. Blum, Symbolism [in:] International Dictionary of Psychoanalysis, A. de Mijolla (ed.), Detroit 2005; E. Jones, op. cit., pp. 102-105.

${ }^{7}$ H. Enckell, op. cit., pp. 1093-1114.

${ }^{8}$ Cf. A. Gibeault, Symbolization, Process of [in:] International Dictionary of Psychoanalysis, op. cit., pp. 1712-1714.

${ }^{9}$ P. Ricoeur, Freud and Philosophy. An Essay on Interpretation, New Haven-London 1970.

${ }^{10}$ H. Enckell, op. cit., p. 1101, passim. 
I propose that the motif of the "vagina dentata" might contain, beyond the archaeological value, a metaphorical potential: its contemporary and contextualised readings might carry the seeds of a deeper recognition of the resources of female agency in the public discourse, and solicit a conscious disentanglement from the multiple declensions of power through which women are made voiceless.

\section{The "vagina dentata" motif in Indian folklore and myths}

The richest collection of narrations about the "vagina dentata" topos in Indic folkloric literature is represented by the work ${ }^{11}$ of Verrier Elwin, who, during his fieldwork in central India, gathered a remarkable repertoire of tales. The aim of the Myths of Middle India anthology was to offer a portrait of the common beliefs around creation, lifestyle and religion that, according to Elwin, were shared by the people of Middle India, under the influence of the "all-pervading Hindu tradition." 12

Elwin maintains that the idea of a vagina endowed with perilous "teeth" is expressed, beyond that of the "vagina dentata" itself, by two other symbols: the snake and long pubic hair. ${ }^{13}$ These emblems have been interpreted as depictions of the inherent dangerousness of female sexuality, ${ }^{14}$ before which men risk losing their power. In order to avoid the outrage, these obstacles must be removed, exposing women to a consequent physical and sexual violence. Once the teeth have been taken away, female characters have no other possibility than to surrender to the male will and be domesticated as wives. ${ }^{15}$ Following scholarly research carried out by Wendy Doniger O'Flaherty ${ }^{16}$ and Sudhir Kakar, ${ }^{17}$ I found occurrences of "vagina dentata" myths in

${ }^{11}$ V. Elwin, Myths of Middle India, Madras 1949.

12 Ibidem, p. 6.

13 Ibidem, p. 244, p. 250, p. 255.

${ }^{14}$ S. Freud, A General Introduction to Psychoanalysis, op. cit., lesson X, pp. 122-140; S. Freud, The Interpretation of Dreams, J. Strachey (trans. and ed.), New York 1955, p. 370; S. Freud, Medusa's Head [in:] Standard Edition, vol. 18, London 1922-1955, pp. 273-274; G. Obeyesekere, Medusa's Hair. An Essay on Personal Symbols and Religious Experience, Chicago 1981, pp. 33-37. In particular, the cutting of hair in Freud is referred to as symbolising castration. I would like to draw a parallel with Obeyesekere's interpretation of the "matted hair" of Hindu female ascetics as a "sublate penis" (Obeyesekere, op. cit., p. 37) emerging from the head. In this case, it is a divine phallus, obtained as a gift for having renounced sex. The long "matted" pubic hair of Elwin's legends could therefore hide a secret phallus, reinforcing the image of the "phallic mother." Nonetheless, as Freud states in his essay on the head of Medusa, the multiplication of penises in the form of snakes (which are Medusa's hair) has a mitigating effect on the horror of the castrated female genitalia.

15 J. Raitt, The "Vagina Dentata" and the "Immaculatus Uterus Divini Fontis", "Journal of the American Academy of Religion" 1980, vol. 48, no. 3, pp. 415-431.

${ }^{16}$ W. Doniger O'Flaherty: Hindu Myths. A Sourcebook Translated from Sanskrit, Harmondsworth 1976; Sacred Cows and Profane Mares in Indian Mythology, "History of Religions" 1979, vol. 19, no. 1, pp. 1-26.

${ }^{17}$ S. Kakar, The Inner World. A Psycho-analytic Study of Childhood and Society in India, Delhi 1982. 
the Padma ${ }^{18}{ }^{18}$ atsya ${ }^{19}$ and Skanda ${ }^{20}$ Purāna; in the first text, the demon Sukra is punished by Siva through constriction in a vulva endowed with fangs, while in the latter two the demon Āḍi takes the form of Pārvatī/Umā and places sharp teeth in her vagina, in order to deceive Siva and kill him. In both representations, the "vagina dentata" is a malignant device through which male characters are neutralised or punished, a clear-cut symbolisation of the dreadful and mysterious powers attributed to the female sexual organs. However, despite the cited works, a further and more indepth exploration of this topic in Hindu mythology is still needed.

\section{First reading: psychoanalytical interpretations of the motif}

I have selected an illustrative folktale narrated by the Agaria people from the village of Bhoira, located in the Mandla District of Madhya Pradesh. According to Russell, Hīra Läll, ${ }^{21}$ and Elwin, ${ }^{22}$ that of the Agaria is a small Dravidian branch of the Gond tribe, whose occupational field is iron-smelting and metal working. The 1911 Census of India reported that the population of the Agaria tribes amounted to 9500 people and that they resided mainly in the Maikal range, in the districts of Mandla, Raipur and Bilāspur. ${ }^{23}$ At the time when the survey was compiled, the Agarias believed that each gotra descended from the same ancestor, therefore marriage within the same gotra was prohibited. Nonetheless, there were two endogamous sub-groups, the Patharia and Kunthia Agaria. Generally, outsiders were not admitted in the caste, and sharing food with a member of a lower caste was punished with permanent excommunication, the same repercussions reserved for adultery. Marriages were usually arranged and, after the ceremony, the bridegroom did not visit the spouse for one month, in order to confirm that she was not already pregnant ${ }^{24}$ : this could particularly be linked to the custom of prenuptial sex described by Elwin as being common to the members of the researched tribes. ${ }^{25}$ Agaria worshipped a family god called Dulha Deo and the Iron Demon, Loha-Sūr, while in the forest areas they also paid reverence to the main god of the Gonds, Bura Deo; on specific occasions they also worshipped their work tools. ${ }^{26}$ Elwin states that Agaria practised totemism, correlating this fact to a very rare occurrence of clan and kinship incest. ${ }^{27}$ Moreover, witchcraft

${ }_{18}$ Padma-Purāna, trans. and annotated by N.A. Deshpande, vol. VII, Delhi 1990, 17.81-89, pp. 2381-2382.

19 The Matsya Puranam, trans. Taluqdar of Oudh, vol. II, Allahabad 1917, 156.11-39, pp. 110-111.

20 The Skanda Purāna, vol. II, Delhi 1950, 29.8b-32, pp. 236-238.

${ }^{21}$ R.V. Russell, R.B. Hīralāl, The Tribes and Castes of the Central Provinces of India, vol. II, London 1916.

22 V. Elwin, The Agaria, London 1942.

${ }^{23}$ J.T. Marten, Census of India, vol. X, part I, Allahabad 1912.

${ }^{24}$ R.V. Russell, R.B. Hīralāl, op. cit., pp. 3-8.

${ }_{25}$ V. Elwin, Myths of Middle India, op. cit., p. 251.

${ }^{26}$ R.V. Russell, R.B. Hīralāl, op. cit., pp. 3-8.

27 V. Elwin, The Agaria, op. cit., pp. 68-85. 
and menstruating women were regarded as sources of danger among the Agaria; in particular, they were held capable of setting fire to the smithy, damaging the furnace or reducing the ore to dross. ${ }^{28}$ In this regard, the connection between menstrual blood and fire sheds light on the "vagina dentata" symbol, highlighting the hazards implicitly posed by sexual intercourse with adult women. ${ }^{29}$

With regard to the status of women in tribal societies, it is generally acknowledged that the indicators for evaluating it are education, employment status and decisionmaking power. ${ }^{30}$ While a widespread idea holds that tribal societies are relatively more egalitarian than societies based on caste hierarchies, especially in relation to work employment and earning capacities, ${ }^{31}$ access to education for women is extremely limited and their living conditions are tougher due to chronic malnutrition and a significant imbalance in the control of material and social resources. While, on the one hand, their active role in the economic sphere allows for a considerable decision-making autonomy in the familial realm, on the other hand the high rate of female illiteracy points to a scarce appraisal of the benefits derived from education. By contrast, a higher pragmatic value is bestowed upon women when they are recruited as labourers and cultivators. ${ }^{32}$ The majority of the tribal population works in the agricultural sector. As such, tribal women are primarily occupied in agricultural activities: their role is seen as complementary to men's and as vital for the local economic system; apart from the tasks related to food processing and cooking, childrearing, domestic chores and looking after the cattle are considered activities that pertain to women exclusively. ${ }^{33}$ Since child labour is commonplace and bride dowry is not required, the bias towards female children is attenuated and practices like sex selection and female foeticide do not normally occur, ${ }^{34}$ although some cases have been documented. ${ }^{35}$ In spite of tribal women's pivotal role in the economic sphere, the public domain is still hardly accessible to them. Although not segregated or confined to the domestic domain only, they witness a severely curbed participation in political or religious life, and their social influence is restricted to children's socialisation and

${ }^{28}$ Ibidem, pp. 119-120, 252, passim.

${ }^{29} \mathrm{Cf}$. the following dreams told by Agaria to Elwin: 1 - "A girl was blowing the bellows in front of the furnace, when fire caught the smithy. I went to put it out and caught the girl and went to her, putting fire in her vagina. Then a man came and pushed me into the fire."; 2 - "I was making charcoal in the forest. The trees caught fire. I ran away. Two women with very big teeth came, and one said, 'I'll swallow him', and the other said, 'I'll put him in my vagina."' See ibidem, p. 120.

${ }^{30}$ V. Bhasin, Status of Tribal Women in India, "Studies on Home and Community Science" 2007, vol. 1, issue 1, p. 1; P. Chatterjee, Social and Economic Status of Tribal Women in India - The Challenges and the Road Ahead, "International Journal of Interdisciplinary and Multidisciplinary Studies" 2014, vol. 2, no. 2, pp. 55-60; M. Awais, T. Alam, M. Asif, Socio-economic Empowerment of Tribal Women: An Indian Perspective, "Indian Journal of Rural Studies" 2009, vol. 16, issue 1, pp. 1-11.

31 V. Bhasin, op. cit., p. 2.

32 Eadem, op. cit., passim; M. Awais, T. Alam, M. Asif, op. cit., pp. 4-5.

33 Eadem, op. cit., p. 9.

34 Ibidem, p. 6.

35 ACHR, Female Foeticide in Tribal India: India's Last Vestige Falls, 2007, http://stopfemaleinfanticide.org/files/STReport.pdf [access: 16.02.2018]. 
preservation of the oral tradition, to the benefit of the reinforcement of an idealised model of woman as a caregiver and housekeeper. ${ }^{36}$

The selected tale goes as follows:

There were seven brothers who set out to find the Maiden Bijnakin. But the youngest had a running nose and the others left him behind in scorn. After many days the six brothers [...] reached the place where Bijnakin and her sister Gajdantar lived. Gajdantar said, "Each of you must sleep with me for a night. If you can conquer me, you can take both of us away. If not, I will turn you into girls." Now in that girl's vagina were teeth and the opening was covered with very long hairs. When the first brother went to her, he found these hairs woven criss-cross over the opening, and he could not thrust his penis through them. So he lost power. Gajdantar laughed at him and made a hole in his nose and put a cowrie in it and bangles on his wrists and shut him up in a separate house. This was the fate of each of the six brothers, and for a long time they lived there impotent. But the youngest brother followed them. On the way he met a fox who told him what had happened and advised him what to do. The boy got a sharp arrow-head and a pot of curds and an iron rod as thick and long as his own penis. Then he greeted Gajdantar and went in to her. First he smeared her hairs with curds and cut them off with the arrowhead. He inserted the iron rod and broke off the teeth that were in her vagina, and then enjoyed her. He had conquered and went to Bijnakin to carry her off. But she begged him to wait seven days. In that house were seven rooms; in one lived the six brothers, in one Gajdantar, in one Bijnakin, in one the youngest boy, in one food and in one a Rakshasa with thick skin and long hair who copulated with men. Bijnakin thought, "If this boy stays here seven days he will sooner or later go into the Rakshasa's room and the Rakshasa will go to him and for shame the boy will run away." But when the boy actually met the homosexual demon, he vanquished him by threatening to set fire to his hair. The demon saved himself by telling the boy where Bijnakin's life-index was hidden. The boy obtained this and by its means rescued his brothers, restored their potency and took the girl home. ${ }^{37}$

As mentioned earlier, the symbol of the toothed vagina is often linked to that of pubic hair: if it is legitimate to suspect that it is a particular category of hair, we may note that, while a common interpretation set forth by Freud states that pubic hair is meant to conceal the absence of the penis in women, ${ }^{38}$ many theorists tend to associate haircutting mainly with castration, but also with separation from the maternal object and reparation..$^{39}$ Furthermore, Elwin states that it is a custom of the women of the tribe to cut pubic hair, as it is seen as repulsive and capable of causing impotence. ${ }^{40}$

The youngest of the seven brothers is the hero of the story, even though, at the beginning, he is scorned because of his "running nose." Since it is well known that the nose symbolically stands for the penis, it is possible to infer that the main character

${ }^{36}$ V. Bhasin, op. cit., passim.

${ }_{37}$ V. Elwin, Myths of Middle India, op. cit., pp. 256-257.

${ }^{38}$ S. Freud: Three Contributions to the Sexual Theory, New York 1910; New Introductory Lectures on Psycho-Analysis, trans. W.J.H. Sprott, New York 1933, Lecture XXXIII, pp. 180-181; M. Schneider, Femininity [in:] International Dictionary of Psychoanalysis, op. cit., p. 574.

39 J.J. Andersen, Rapunzel: The Symbolism of the Cutting of Hair, "Journal of the American Psychoanalytic Association" 1980, vol. 28, issue 1, pp. 69-88. In order to provide references for the analogies between haircutting and castration anxieties, Andresen quotes the works of Freud, Abraham, Berg, Monroe and Abse, Simmel and Sperling; S. Freud: Leonardo da Vinci. A Memory of His Childhood, London 1957, p. 44; Medusa's Head, op. cit., pp. 273-254.

${ }^{40} \mathrm{~V}$. Elwin, Myths of Middle India, op. cit., p. 255. 
is intended as a child, whose sexual functions and control over ejaculation are still unripe, for which reason his mature virility is questioned by the older brothers. However, the "runny nose" with its uninterrupted fluid availability could symbolise the "superphallic male," ${ }^{41}$ whose sexual insatiability must be preserved by way of a violent removal of the obstacles. The two interpretations are not necessarily in contradiction if the perspective of symbolised anxieties related to impotence/castration is adopted here. When the "non-superphallic" brothers approach the maiden, indeed, they are made impotent by her sister. It is not necessary that a physical emasculation takes place: following the impossibility of penetrating her, the six men's noses are pierced and a symbol of female genitalia, the cowrie, is applied to the nostrils, as to say that they are castrated and forced to live as women. ${ }^{42}$ After some time, the youngest brother enters the maiden's house and follows the instructions provided by the fox ${ }^{43}$ : as a result, he wins both the women, but is asked to wait for a week in order to claim his prey. Why does Bijnakin wish to buy her time? She hopes that the youngest boy could fall victim to the homosexual appetite of a demon who shares the house with the two sisters, and so abscond out of shame. It was said that the Rākșasa has long hair: its castrating power is then pointed out in a twofold way, namely through the awakening of anxieties connected to the displayed phallic symbolism and through the menace of submission to a male authority in consequence of homosexual intercourse, a possibility unmistakably regarded as shameful in Bijnakin's intentions. As a defence against this dreadful scenario, the hero of the story threatens the demon to burn his hair, superimposing a castration menace to the one put forward by the Rākșasa. In the end, he saves the brothers, restores their virility thanks to an obscure "life-index," and marries the maiden.

Gajdantar is portrayed as a sexually dangerous witch (she can transform men into women, her "life-index" can restore male potency, she shares the house with a demon, etc.) whose vagina is provided with elements which castrate every man who demands her sister. She excogitates cunning plans to protect her familial arrangement, but she must capitulate when the young hero deprives her of her weapons by curd - a possible replacement for semen ${ }^{44}$ - an arrowhead and a self-evident phallic surrogate, the iron rod. Otero reports that, in North and South American folklore, the culture-hero resorts to a "superphallus" made of stone in order to make copulation possible ${ }^{45}$; in this tale I consider the iron rod as a "superphallus," whose emblematic

${ }^{41}$ S. Otero, "Fearing our Mothers": An Overview of the Psychoanalytic Theories Concerning the "Vagina Dentata" Motif F547.1.1, "The American Journal of Psychoanalysis" 1996, vol. 56, no. 3, pp. 269-288.

${ }^{42}$ It is common for Indian women to wear nose piercings and bangles, and the practice of having nostrils pierced is recommended by the Suśruta Samhitä of the Ayurveda, due to the benefits for reproductive health. Cf. M. DeMello, Faces Around the World: A Cultural Encyclopedia of the Human Face, Santa Barbara, CA 2012, pp. 239-240. The analogy between sea snails and female genitals is given by Freud, The Interpretation of Dreams, op. cit., lesson X.

${ }_{43}$ The fox is a furry animal, and fur is associated by Freud with pubic hair and female genitals: is this another allusion to the dangers of the astuteness and deceitfulness of women?

${ }^{44}$ On the analogy between milk and semen, see: W. Doniger O'Flaherty, Women, Androgynes, and Other Mythical Beasts, Chicago-London 1980, pp. 32, 43, passim; S. Otero, op. cit., p. 272.

${ }^{45}$ S. Otero, op. cit., p. 276. 
value will be stressed in the second part of the paper. In the end, only after the witch is tamed their virility can be restored: the seven brothers return as men, winning the right to marry the maiden.

In her article, ${ }^{46}$ Jill Raitt discusses the "vagina dentata" motif as the atavistic masculine fear of female wild sexuality and, especially, of the womb, an obscure and deep cave, yet one capable of giving life. I am inclined to acknowledge in this symbolism not the "penis envy" theorised by Freud, but rather "womb envy," the removal of the teeth not only the most obvious defence against castration anxiety, but also an envious act of aggression towards such a mighty and enigmatic source of life and nurturance. In this regard it is interesting to note that Girindrasekhar Bose, the first president of the Indian Psychoanalytic Society, encountered in some of his male patients a wish to be female and to bear children. ${ }^{48}$ Actually, the sole interpretation of "teeth" as phallic substitutes leading to the generation of a "phallic mother" is not fully satisfactory here, because it neglects the weight of male projections on the maternal figure, by reason of a feared retribution for the sadistic impulses primarily directed to her breast. This unconscious terror of punishment by a loved but frightful mother could be one source of the appearance of such a symbol. Moreover, as the womb is associated with motherhood, it might be possible to argue that one reason why the uterus is interspersed with discouraging weapons is that they are a warning against the dangers associated with maternal incest. However, in this case, what does the removal of the obstacles represent? Should it be read as an aggressive fantasy directed towards an ambivalent, seductive and devouring mother? ${ }^{49} \mathrm{Or}$ as the desire to conquer her without hindrances of any sort? While it is arduous to conclude that every "vagina dentata" tale hides such an incestuous wish, it might be important to remark that the snake emerging from the uterus or the pubic hair could be intended as a phallic symbol, warning against the pitfall of emasculation by a male authority. This interpretation finds a connection with the "vagina dentata" myth found in the Padma-Purāna,$^{50}$ and narrated by Wendy Doniger as follows:

Sukra had the power of reviving demons who fell in the battle between gods and demons. To prevent him from using this power, Śiva swallowed Śukra, but when praised by Śukra, Śiva released him [...] As he emitted Śukra through his penis, henceforth Śukra was called Śukra (sic), "semen." As he emerged, Śiva still wished to harm him, but Devī, the goddess, interceded, pointing out that as he had come out of Śiva's phallus, Śukra was now not only an immortal but her son. Siva then let Śukra go. ${ }^{51}[. .$.$] Śukra continued to use his mantra of immortality to revive$ all the demons who fell during the battle. Śiva, knowing that Śukra could not be killed (perhaps because he, Siva, had once swallowed him), created a horrible woman with a mouth like a great

${ }^{46}$ J. Raitt, op. cit., pp. 415-431.

${ }^{47}$ Cf. K. Horney, Feminine Psychology, New York-London 1967.

${ }^{48}$ G. Bose, S. Freud, The Beginning of Psychoanalysis in India: Bose - Freud Correspondence, Calcutta 1999.

${ }^{49}$ Cf. S. Kakar, op. cit.

${ }^{50}$ Padma-Purāna, op. cit., pp. 2381-2382.

${ }^{51}$ This antecedent is narrated in Mahābhārata 12.258.1-38, cf. Mahābhārata, translated from the original Sanskrit text by P.C. Roy, Second Revised Edition, vol. 8, Calcutta 1965, pp. 374-376. 
cavern, with teeth and eyes in her vagina. At Śiva's command, she grabbed Śukra and stripped him and embraced him, and she kept him inside her until the battle was over. ${ }^{52}$

The fight between Sukra and Siva is the fight of a son against his father: the god emits the demon with his own semen, pushing Devi to recognise him as his son and to save his life. At a later stage, in order to subdue him, Śiva has to create a woman whose uterus has sharp teeth and eyes: after undressing him, she entraps him, presumably tightening his penis within her toothed vagina. The perilousness of the female sexuality is identified with the monstrous woman equipped with a cavern as mouth and possessing teeth and eyes in the uterus. It is possible to track down the theme of the incest, given the roles of Devī as a sympathetic mother, of Siva as a father and of Śukra as a vengeful son. Although the wish to possess the mother is not overtly expressed here, in my opinion the punishment of the entrapment in the toothed vagina could be considered as a threat against incestuous desires towards the mother. Otherwise, why should Śiva devise such an exemplary retribution?

\section{Second reading: making women defenceless and voiceless}

The iconic power of the removal of the teeth is not confined to tales and myths: I will try to interpret it as the patriarchal will of silencing women by depriving them of the faculty of defence. As a matter of fact, fangs in the animal world are an effective tool that allows predators to assault their prey, but is also utilised to defend them from enemies. The popular saying "to show one's teeth" points to the reaction against someone or something threatening, the display of an aggressive behaviour in order to protect one's own safety. Symbolically, a vagina endowed with teeth might represent the attempt of vulnerable prey to defend themselves against any kind of violence perpetrated by powerful males, whose main goal is to assert their supremacy over them. Following this argument, I suggest an interpretation of the toothed vagina motif based on my personal understanding of recent cases of rapes in India.

When reading news reports about the infamous Delhi gang rape, one thing in particular stands out: one of the elements of coercion used by the persecutors of the young victim was an iron rod used to torture her. According to the Firstpost online newspaper, for instance, the victim underwent various surgeries because of intestine damage "after being repeatedly hit with a blunt object on her abdomen, and doctors say the extent of genital damage indicates that a blunt object was also probably shoved up her private parts. ${ }^{, 53}$ When reactivation of symbolism is at stake, ${ }^{54}$ the tale

52 W. Doniger O'Flaherty, Sacred Cows and Profane Mares in Indian Mythology, op. cit., p. 20.

${ }_{53}$ Delhi Gangrape Victims Regains Consciousness, http://www.firstpost.com/india/delhi-gangrapevictim-regains-consciousness-next-48-hours-critical-561535.html [access: 30.01.2018].

${ }^{54}$ I do not intend to state that symbols are universal because they belong to a sort of "collective" and shared unconscious. Rather, if we agree upon the fact that "[p]sychoanalytic symbols emerge as a result of the interaction of the instinctual drives, defences, and other ego functions with the developmental experience of the infant and child" (H.P. Blum, op. cit., p. 1711), we can hypothesise that the peculiar and contextual events of ministration due to the role of mothers as primary caregivers in patriarchal societies 
of the Agaria man cannot fail to come to mind: the teeth in the vagina were removed with an iron rod, which I have identified as a "superphallus." In Bihar in October 2017, as reported by the online newspaper "india.com", a 35-year-old woman was killed by a younger man who, after various frustrated rape attempts, maimed her with an iron rod. ${ }^{55}$ Sadly, the list is far too long to be summarised here. What must be recognised is that violence, and peculiarly physical violence, acts as a symbolic "teeth" removal, because it forcibly excises the possibility of self-defence, in favour of the attempt of controlling and taming women's bodies and lives.

This is not the only kind of gendered aggression against women. A subtler one predicates in favour of their "impossibility to choose." In her book, ${ }^{56}$ Gita Aravamudan confronts the thorny issue of female foeticide and infanticide in small villages of the state of Tamil Nadu. According to her reports, many mothers are forced to comply with the decision of the family and to accept abortion or having their female child gruesomely murdered. When asked, the members of the community declared that a woman has no other choice than to obey, otherwise she would lose her respectability, family, house, and even her life too. What the society expects from a woman is silence and submission, and the means to obtain such deference are well codified. As a young Indian man told me during an interview, ${ }^{57}$ women living in small villages in rural areas are illiterate and heavily dependent on the community for survival. The suggestion of laying claim to their rights is remote, therefore a woman:

has no choice: imagine being in a small village. [...] the guy next door has a rickshaw that will take you $50 \mathrm{~km}$ to take the bus. You decide to leave: where will you go? That guy next door won't take you because he knows if he does he is going to be butchered. So, if you decide to walk how far will you walk? Soon enough you will be brought back and tortured. [...] you don't know anyone outside your village, you don't know how to gather your own food: then how do you survive?

If, on the one hand, the removal occurs by depriving women of economic independence and/or of the right of self-determination, on the other hand it takes place through a resolved denial of their moral capability. Once the chances of protecting herself from the familial and societal constrictions have been eradicated through systematic devaluation and physical abuse, the possibility of opposing the status quo is further undermined by a widespread portrayal of women as victims and morally

may result in such a symbolism, and that such symbolism reproduces itself within a male dominated sex/gender organisation (see G. Rubin, The Traffic in Women: Notes on the "Political Economy" of Sex, "Monthly Review Press" 1975, Toward an Anthropology of Women, R.R. Reiter [ed.]). I justify in this way the connection of my interpretation of symbols from mythology and folklore with my reading of the symbolism that, in my view, emerges from contemporary news reports.

${ }_{55}$ Bihar Man Inserts Iron Rod Into a Woman's Private Parts After Failed Rape Attempt and Kills Her, http://www.india.com/news/india/bihar-man-inserts-iron-rod-into-womans-private-parts-after-failedrape-attempt-kills-her-2530707/ [access: 30.01.2018].

${ }^{56}$ G. Aravamudan, Disappearing Daughters: The Tragedy of Female Foeticide, New Delhi-New York 2007.

${ }^{57}$ What follows is an excerpt from an interview with a middle-class Indian man in his thirties, from Kolkata and working as a researcher in physics. The interview took place in August 2017 in Rome, where he was living at the time. 
weak beings. This depiction may foster identification, exalting a misleading model of womanhood which has no choice but to adhere to the will of the patriarchal institutions and relinquish her potential influence. I am aware, however, of the fact that the power dynamics of victimisation has many nuances and purposes, including disavowal. This is the case, for instance, of the Indian \#MeToo movement. This phenomenon, propagated through social media since October 2017, witnessed an uproar of female voices against sexism and harassment. Simultaneously, almost obsessive attempts to suppress the same female voices through denial, downplaying or insinuation of a shared responsibility often ended up turning the victims into victimisers..$^{58}$

It is exactly at this intersection that the metaphorical significance of the "vagina dentata" motif discloses some of its opportunities: the "teeth" to be safeguarded from aggression are, once again, women's voices, speaking in favour of their own active participation in the public domain, in defence of their own self-determination, security in private and public places, equal access to political, religious and cultural discourses, including self-realisation. If teeth are dangerous devices, voices are even more dangerous: in quality of assertive - not only defensive - implements, they are well equipped to bite all the "grab "em by the pussy" ${ }^{59}$ ideologies.

\section{Conclusions}

In the first part of the paper I discussed the "archaeological" value of the symbol of the "toothed" vagina. I focused on its possible interpretations and suggested that castration anxieties, defence against a fantasised ambivalent mother, incestuous wishes and womb envy could be sources of this symbolisation. In the second part I tried to emphasise the connection between the symbol of the "vagina dentata" and some of the devices through which patriarchal societies impose male supremacy on women, namely physical abuse, economic dependence and minimisation of the capacity of women to contribute to the public discourse. Furthermore, I suggested a metaphorical resource enclosed in the symbolism of the "vagina dentate." As Monica Melanchthon advises,${ }^{60}$ it is necessary to recognise the multiple factors that contribute to the subaltern status of women in Indian society, and particularly the interrelation of gender, caste and class. In addition, it is essential to reinstate women's right to have a voice, for instance through the practice of storytelling, because within it "[t]he narrating of the story becomes a vehicle for understanding attitudes, cultural taboos, relationships

${ }^{58} \mathrm{Cf}$. the Sheena Dabholkar incident at https://www.hindustantimes.com/analysis/metoo-does-ittake-a-twitter-trend-for-men-to-know-women-are-harassed-every-day/story-c8InKAyvFnBALNxejogTEL.html [access: 14.02.2018]; on the \#MeToo movement in India: \#MeToo: Indian Victims Sexual Assault, https://theprint.in/2017/10/16/me-too-indian-victims-sexual-assault/ [access: 20.02.2018].

${ }^{59}$ Cf. Donald Trump's taped statement on women: Donald Trump Tape Transcript, https://www. nytimes.com/2016/10/08/us/donald-trump-tape-transcript.html [access: 20.02.2018].

${ }^{60} \mathrm{M}$. Melanchton, Indian Dalit Women and the Bible: Hermeneutical and Methodological Reflections [in:] Gender, Religion and Diversity. Cross-Cultural Perspectives, U. King, T. Beattie (eds.), London-New York 2005, pp. 212-224. 
in families and kinship networks, and many forms of social behaviour." ${ }^{\circ 1}$ It is possible to rethink the position of women in society only by claiming an active role in the narratives of femininity itself, not only at a popular level, but also through a refashioning of academic knowledge, including the field of religious studies. As pointed out by Ursula King, ${ }^{62}$ this could be achieved on a scholarly level by reaffirming the strong interconnection between gender, culture, religion and, above all, by including the fundamental and influential voices of women as narrators of their own personal stories.

\section{References}

Andersen J.J., Rapunzel: The Symbolism of the Cutting of Hair, "Journal of the American Psychoanalytic Association" 1980, vol. 28, issue 1, pp. 69-88.

Aravamudan G., Disappearing Daughters: The Tragedy of Female Foeticide, New Delhi-New York 2007.

Awais M., Alam T., Asif M., Socio-economic Empowerment of Tribal Women: An Indian Perspective, "Indian Journal of Rural Studies" 2009, vol. 16, issue 1, pp. 1-11.

Bhasin V., Status of Tribal Women in India, "Studies on Home and Community Science" 2007, vol. 1, issue 1, pp. 1-16.

Blum H.P., Symbolism [in:] International Dictionary of Psychoanalysis, A. de Mijolla (ed.), Detroit 2005, pp. 1711-1712.

Bose G., Freud S., The Beginning of Psychoanalysis in India: Bose - Freud Correspondence, Calcutta 1999.

Chatterjee P., Social and Economic Status of Tribal Women in India - The Challenges and the Road Ahead, "International Journal of Interdisciplinary and Multidisciplinary Studies" 2014, vol. 2, no. 2, pp. 55-60.

DeMello M., Faces Around the World: A Cultural Encyclopedia of the Human Face, Santa Barbara, CA 2012.

Doniger O'Flaherty W., Hindu Myths. A Sourcebook Translated from Sanskrit, Harmondsworth 1976.

Doniger O'Flaherty W., Sacred Cows and Profane Mares in Indian Mythology, "History of Religions" 1979, vol. 19, no. 1, pp. 1-26.

Doniger O'Flaherty W., Women, Androgynes, and Other Mythical Beasts, Chicago-London 1980.

Elwin V., Myths of Middle India, Madras 1949.

Elwin V., The Agaria, London 1942.

Enckell H., Reflection in Psychoanalysis: On Symbols and Metaphors, "International Journal of Psychoanalysis" 2010, vol. 91, pp. 1093-1114.

Freud S., A General Introduction to Psychoanalysis, New York 1920.

Freud S., Leonardo da Vinci. A Memory of His Childhood, Routledge 1957.

Freud S., Medusa's Head' [in:] Standard Edition, vol. 18, London 1922-1955, pp. 273-275.

Freud S., New Introductory Lectures on Psycho-Analysis, trans. W.J.H. Sprott, New York 1933.

Freud S., The Interpretation of Dreams, J. Strachey (trans. and ed.), New York 1955.

Freud S., Three Contributions to the Sexual Theory, New York 1910.

${ }^{61}$ Ibidem, pp. 221-222.

${ }^{62}$ U. King, General Introduction: Gender-Critical Turns in the Study of Religion [in:] Gender, Religion and Diversity. Cross-Cultural Perspectives, op. cit., pp. 1-10. 
Gibeault A., Symbolization, Process of [in:] International Dictionary of Psychoanalysis, A. de Mijolla (ed.), Detroit 2005, pp. 1712-1714.

Horney K., Feminine Psychology, New York-London 1967.

Jones E., Papers on Psycho-analysis, $5^{\text {th }}$ edition, London 1977.

Kakar S., The Inner World. A Psycho-analytic Study of Childhood and Society in India, Delhi 1982.

King U., General Introduction: Gender-Critical Turns in the Study of Religion [in:] Gender, Religion and Diversity. Cross-Cultural Perspectives, U. King, T. Beattie (eds), London-New York 2005, pp. 1-10.

Laplanche J., Pontalis J.B., Enciclopedia della Psicoanalisi. Tomo Secondo, Bari 2010.

Mahābhārata, translated from the original Sanskrit text by P.C. Roy, Second Revised Edition, vol. 8, Calcutta 1965.

Marten J.T., Census of India, vol. X, part I, Allahabad 1912.

Melanchton M., Indian Dalit Women and the Bible: Hermeneutical and Methodological Reflections [in:] Gender, Religion and Diversity. Cross-Cultural Perspectives, U. King, T. Beattie (eds.), London-New York 2005, pp. 212-224.

Obeyesekere G., Medusa's Hair. An Essay on Personal Symbols and Religious Experience, Chicago 1981.

Otero S., "Fearing our Mothers": An Overview of the Psychoanalytic Theories Concerning the "Vagina Dentata” Motif F547.1.1, "The American Journal of Psychoanalysis" 1996, vol. 56, no. 3, pp. 269-288.

Padma-Purāna, trans. and annotated by N.A. Deshpande, vol. VII, Delhi 1990.

Raitt J., The "Vagina Dentata" and the "Immaculatus Uterus Divini Fontis", "Journal of the American Academy of Religion" 1980, vol. 48, no. 3, pp. 415-431.

Ricoeur P., Freud and Philosophy. An Essay on Interpretation, New Haven-London 1970.

Rubin G., The Traffic in Women: Notes on the "Political Economy" of Sex, "Monthly Review Press" 1975, Toward an Anthropology of Women, R.R. Reiter (ed.), pp. 157-210.

Russell R.V., Hīralāl R.B., The Tribes and Castes of the Central Provinces of India, vol. II, London 1916.

Schneider M., Femininity [in:] International Dictionary of Psychoanalysis, A. de Mijolla (ed.), Detroit 2005, p. 574.

The Matsya Puranam, trans. Taluqdar of Oudh, vol. II, Allahabad 1917.

The Skanda Purāna, vol. II, Delhi 1950.

\section{Webliography}

\#MeToo: Does It Take a Twitter-Trend For Men To Know Women Are Harassed Every Day?, https:// www.hindustantimes.com/analysis/metoo-does-it-take-a-twitter-trend-for-men-to-know-women-are-harassed-every-day/story-c8InKAyvFnBALNxejogTEL.html [access: 14.02.2018].

\#MeToo: Indian Victims Sexual Assault, https://theprint.in/2017/10/16/me-too-indian-victims-sexual-assault/ [access: 20.02.2018].

ACHR, Female Foeticide in Tribal India: India's Last Vestige Falls, 2007, http://stopfemaleinfanticide.org/files/STReport.pdf [access: 16.02.2018].

Bihar Man Inserts Iron Rod Into a Woman's Private Parts After Failed Rape Attempt and Kills Her, http://www.india.com/news/india/bihar-man-inserts-iron-rod-into-womans-private-parts-afterfailed-rape-attempt-kills-her-2530707/ [access: 30.01.2018].

Delhi Gangrape Victims Regains Consciousness, http:/www.firstpost.com/india/delhi-gangrapevictim-regains-consciousness-next-48-hours-critical-561535.html [access: 30.01.2018].

Donald Trump Tape Transcript, https:/www.nytimes.com/2016/10/08/us/donald-trump-tape-transcript.html [access: 20.02.2018]. 